\title{
Parametric Cost Estimation Model for Li-ion Battery Pack of E-motorcycle Conversion based on Activity Based Costing
}

\author{
Sofi Desi Susanti ${ }^{*}$, Yuniaristanto $^{1}$, Wahyudi Sutopo ${ }^{1,2}$, and Rina Wiji Astuti ${ }^{3}$ \\ 1 Department of Industrial Engineering, Faculty of Engineering, Universitas Sebelas Maret Surakarta 57126, \\ Indonesia; sofidesisusanti@student.uns.ac.id (SDS); yuniaristanto@ft.uns.ac.id (YA); \\ wahyudisutopo@staff.uns.ac.id (WS) \\ 2 National Center for Sustainable Transportation Technology (NC STT), Bandung, 40132, Indonesia \\ 3 CEO of Start-Up Technology, PT Batex Energi Mandiri, Surakarta, Indonesia; rinawijia@gmail.com (RWA) \\ * Correspondence: sofidesisusanti@student.uns.ac.id;
}

\begin{abstract}
Universitas Sebelas Maret (UNS) through SMART UNS Company has conducted research and development of e-motorcycle conversion using Li-ion battery pack as a substitute for ICE energy source from the conventional motorcycle. Currently, the battery-pack that used for emotorcycle conversion is in the development phase towards commercialization. The challenge of estimating production costs is the complicated production process and storing hidden expenses that can be a problem. This hidden cost is often a missing or varied factor that costs less or more expensive. This study presents an integrated parametric cost estimation model with activity-based cost assignments to estimate production costs through cost calculations for each activity. Activitybased costs break the production process into a specific cost element for each step. Each activity's cost is put into a parametric cost estimation model to calculate the cost of each activity into the total cost of production. Cost estimation results will be analyzed using a regression method to determine which variables most affect the production cost of Li-ion battery packs for the conversion of emotorcycles in the SMART UNS company.
\end{abstract}

Keywords: activity-based costing; battery pack; e-motorcycle conversion;

\section{Introduction}

The level of motorcycle sales in Indonesia in 2019 increased by 1.6\% from the same period last year [1]. The motorcycle still uses the Internal Combustion Engine (ICE) technology, which is very influential on the level of fuel oil usage from fossil energy [2]. For ten years, the consumption of fossil fuels increased by an average of 1.3 percent annually [3] and its annual amount of $14 \%$ emissions caused by fossil fuels from the transportation sector. Emissions from the transport sector are mainly coming from vehicles that dominate the release of long-lived greenhouse gases. This makes increased contributions to the total effect of the anthropogenic greenhouse [4]. Emissions resulting from fossil fuels cause an increase in $\mathrm{CO}_{2}$ that results in climate change [5]. The growth rate of $\mathrm{CO} 2$ has a strong correlation with global temperature anomalies with $\mathrm{CO} 2$. Global warming rates have been accelerated in the last decade. The global surface temperature in 2019 is the 2 nd highest in the period of instrumental measurement in the Goddard Institute for Space Studies (GISS) analysis. The global temperature 2019 is $+1.2^{\circ} \mathrm{C}\left(\sim 2.2^{\circ} \mathrm{f}\right)$ warmer than in the base period $1880-1920$ is a reasonable estimate of the 'pre-industrial' temperature [6]. Electric vehicles are automotive products that have capabilities to improve vehicle performance and mitigate the negative effects of the environment [7]. Electric vehicles contribute to the reduction of greenhouse gas emissions evidenced by previous research to date has shown that electric vehicles produce lower greenhouse gas emissions [8]-[9].

One alternative offered as an effort to overcome the problem in this is to use electricity technology to be used as an energy source in all types of vehicles. The use of batteries as energy 
storage devices replace fossil fuels in the ICE system. There are two types of products in realizing electric motorcycles: the new design of electric motorcycles and the conversion of technology from ICE to electric technology. There are several previous studies on the new design of an electric motorcycle, including research conducted by Mutyala [10]; Godlewski \& Pawlak [11]; and Zarandi, Ebrahimi [12]. The second type of electric motorcycle production is conversion electric motorcycle. This motorcycle converts conventional technology into electrical energy through the Battery-Pack, BMS, and Drivetrain, which substitutes motor and engine parts [13]. Although many countries have Produced BEVs, there are fewer researches that have been conducted for e-motorcycle conversion.

SMART UNS has become a company that has conducted research and development on emotorcycles conversion using lithium-Ion batteries as a substitute for ICE energy sources for conventional motorcycles. UNS as a member of the consortium team to develop a national electric vehicle is developing a lithium-ion battery (Li-Ion) for energy storage in electric vehicles. Batterypack test results with power $1 \mathrm{kWh}$ are E-motor conversion can travel about $35-40 \mathrm{~km}$, with speeds that can reach $125 \mathrm{~km} / \mathrm{h}$. This result means that the battery can replace the vehicle's fuel oil. Following the research phase, UNS is currently researching to prepare the commercialization of Li-ion emotorcycle conversion [14].

Technological developments allow electrochemical energy storage based on lithium-ion cells. In order to use the lithium-ion battery massively, one of the major constraints is low system cost [15]. Battery-Pack for the e-motorcycle conversion is a new product manufactured by SMART UNS that has a complicated production process and saves hidden costs. After determining the requirements for a particular vehicle (e.g., maximum speed, acceleration, and range), as well as the cellular portfolio arrangement to be considered in determining investment costs that indirectly affects the production cost [16]. Production costs include many variables, such as materials, machinery, equipment, and labor. These hidden costs often represent missing or unmeasured factors. It is important to estimate the cost to identify and select which variables can be used to determine the battery pack's final price. Revealing these hidden costs is required to make a good decision between making an alternate production process or developing a device. The parametric model approach is the most appropriate in estimating the cost of new products that are still under development [17].

Parametric estimation is a cost estimation technique using mathematical equations to integrate costs with physical parameters related to items to be estimated. In this study, the parametric cost estimation method is integrated with activity-based costing. The activity-based costing method can allocate costs accurately by charging product costs based on the consumption of resources needed for each activity. Horngren [18] states that one of the best ways to estimate costs is to implement a cost calculation system based on activity or activity-based costing (ABC). The main step of Activitybased costing $(\mathrm{ABC})$ is to identify activities based on the system. This method identifies the costs needed for each activity to facilitate cost tracking. This activity improves the cost calculation system by identifying individual activities as fundamental (object) cost objects. Ben-Ariech \& Qian [19] stated that the application of activity-based costing on a parametric cost estimate can improve the accuracy of the calculation. There have been some previous studies using this method conducted by Sutopo, Atikah, Purwanto, Danardono, \& Nizam [14]; Ardiansyah, Sutopo, \& Nizam [17]; Sutopo, Nizam, Purwanto, Atikah and Putri [20]; W. Sutopo; A. Eliza; R. Ardiansyah; Yuniaristanto; and M. Nizam. Parametric [21], MY Abu; KR Jamaludin; and MA Zakaria [22]. The cost estimation model will be analyzed using the regression analysis method to improve the accuracy of the estimated cost's final results and to identify variables that affect the cost of producing lithium-ion battery packs produced by SMART UNS.

Based on the explanation above, it is known that the lithium-ion battery pack for motorcycle conversion moves from research to commercialization, therefore the estimation of production costs to concern. As a new product, the company requires an accurate cost estimation model that can identify each activity element's entire cost to calculate the cost of production of the lithium-ion battery-pack electric convertible motorcycle. Therefore, this research aims to build a parametric cost estimation model of the battery-pack by implementing activity-based costing and identifying the factors that most affect the production cost of battery-pack conversion motors. 


\section{Materials and Methods}

\subsection{Data Collection}

This study developed a parametric cost estimation model with an activity-based costing approach. Figure 1 shows the flow of research using this approach. The initial phase of this research begins with collecting data such as the bill of materials from battery packs and business processes from the SMART UNS company. The bill of materials and business processes of the Li-ion battery pack by SMART UNS are shown in Figure 2 and Figure 3. Through these data, we can identify cost driver rates and cost centers for each activity. Cost driver rates are the main component in the parametric cost estimation model. The estimated cost estimation model is used to calculate production costs.

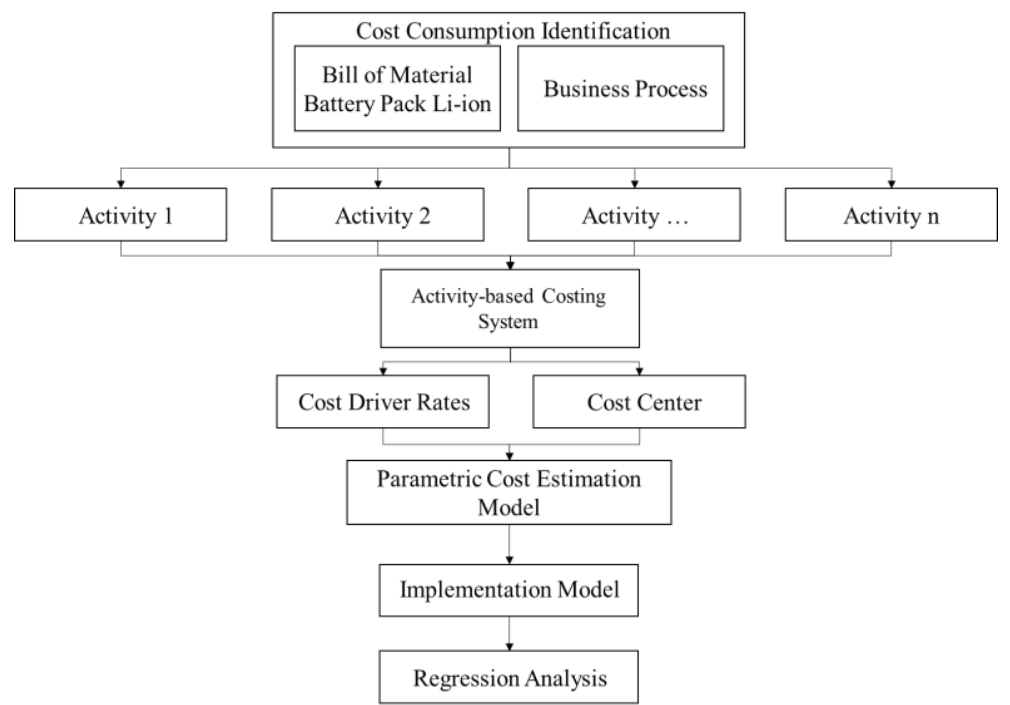

Figure 1. Research Process

The development cost estimation model starts with identifying the BOM Li-ion battery pack. The BOM tree structure of a Li-ion battery is shown in Figure 2. Through the bill of material provides information related to the components forming a Li-ion battery pack. BOM is used as an essential data parameter in product life cycle management that represents product information such as the hierarchical part associated with a particular product. Through multi-levels BOM can be used to determine the engineering bill of materials needed in estimating costs.

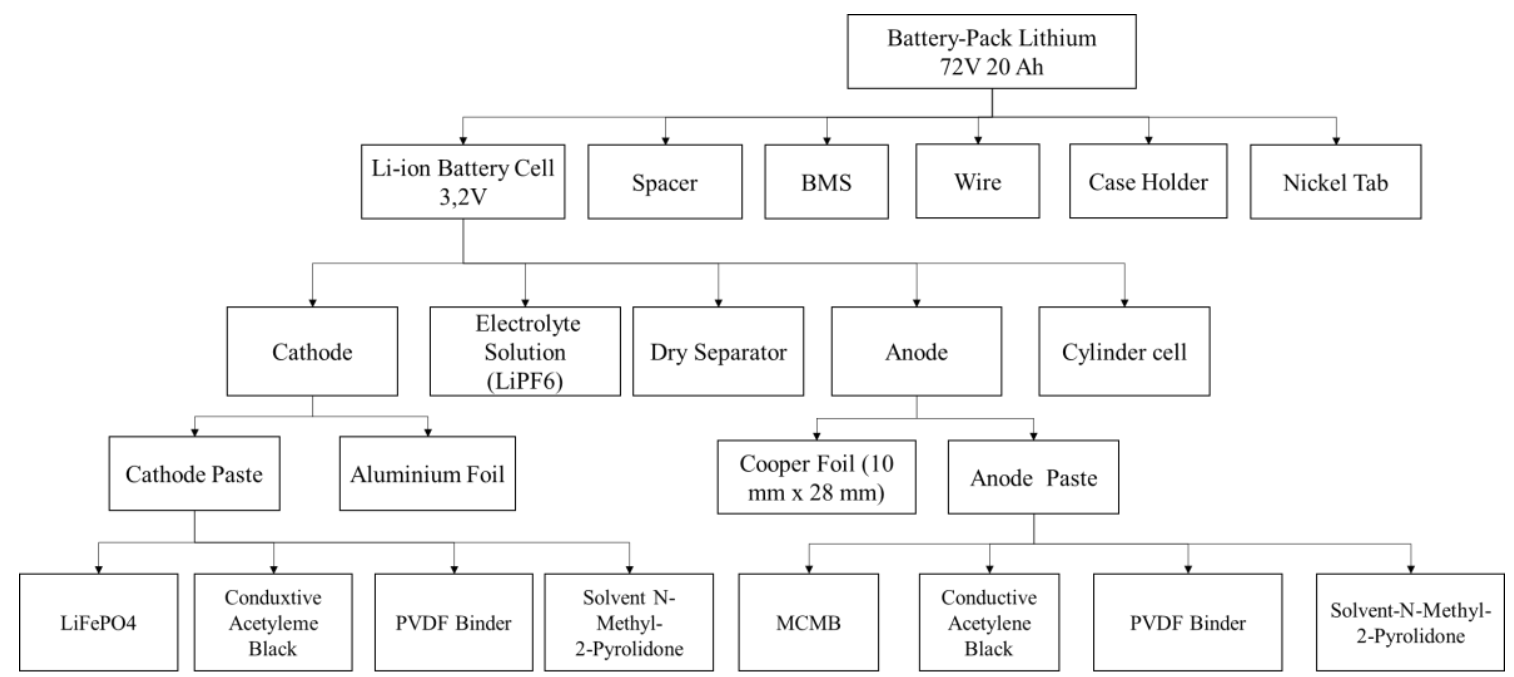

Figure 2. Bill of Material

The business process at SMART UNS is divided into 4 groups, such as management as administration and activities outside of production, the Li-ion battery module team is a group working on a production at the battery module stage. The electrical component assembly team is a 
group working on the production process of the electrical component assembly stage. The charging and testing team is a group that is working on the final stages of the production process, namely charging and final tests. There are two types of li-ion battery packs produced at SMART UNS type A for $150 \mathrm{cc}$ and type B for 110cc. Both models have the same production process, and the difference is the specifications of the material used.

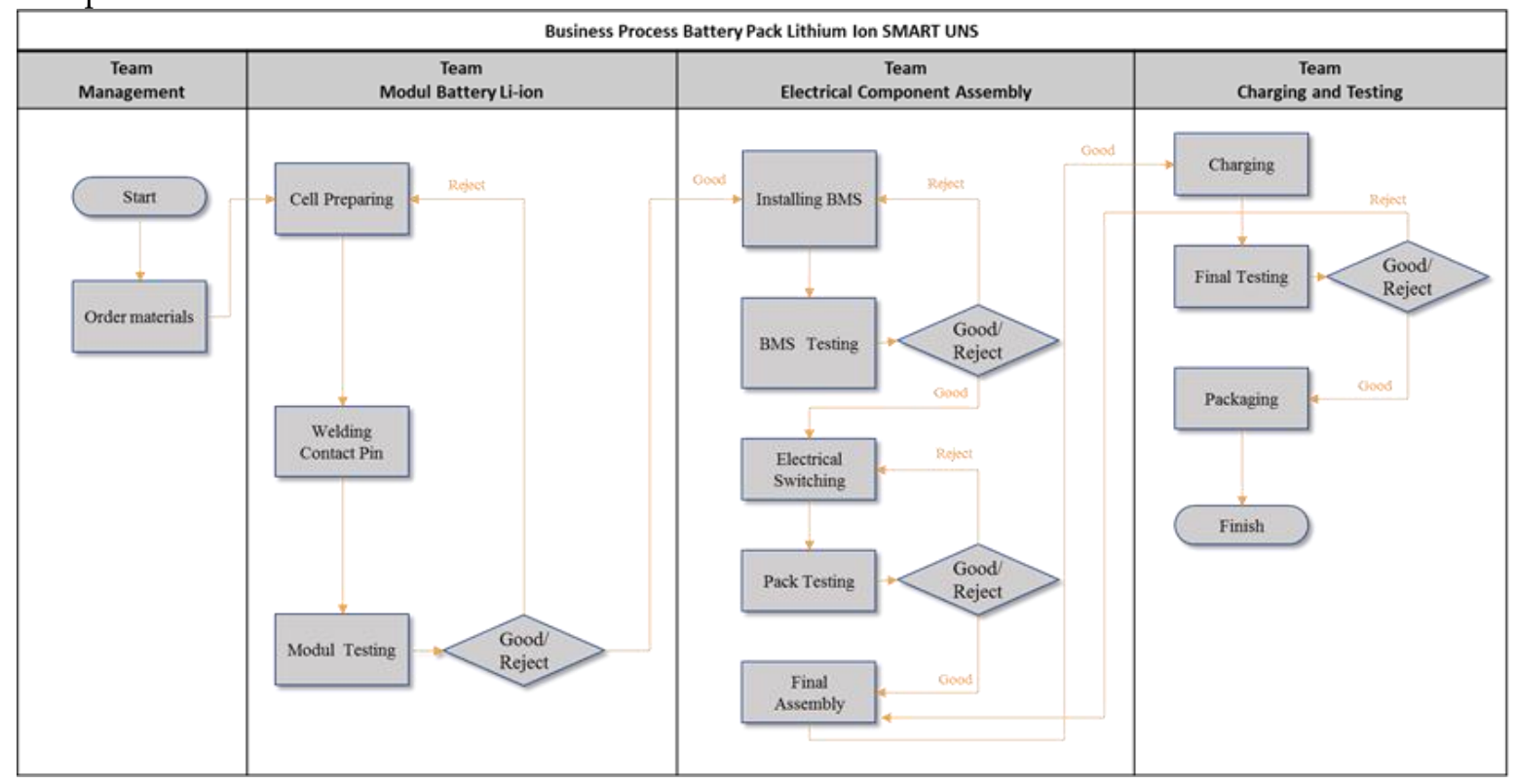

Figure 3. Business Process

\subsection{Cost Driver and Cost Center Identification}

Activity-based costs are developed to get a more accurate cost estimate [23],[24]. The difference between activity-based costing with the traditional system is the determination of cost drivers [25][27]. Cost driver is a driving factor that triggers cost and intermediate factors between cost objects with activities and resources [28]. For selecting the cost driver should be done carefully to ensure the accuracy of the cost. Some researchers have conducted research related to cost drivers as conducted by Cokins and Căpuşneanu [27], Sheng [28], Geiger [29], Răvaş and Monea [30], Dražić-Lutilsky and Dragija [31].

According to Sheng, the cost driver has some specific characteristics such as concealment, relevance, application, and accountability [28]. Cost drivers must have a causality relationship with the activities and costs, it must be measured and explain the use of resources consumed during an activity [30]. Cost drivers should demonstrate correctly the relationship between specific activity and cost objects [31],[32]. One of the requirements of the construction of the cost driver is the cost parameter. Each cost driver relates directly to the process engineering, it can be used in creating task chains. The engineering process associated with this cost driver can be triggered to generate value for cost parameters.

SMART UNS with the business processes that have been described are important for identifying costs associated with various activities in the process, and this is to assess and evaluate inefficiencies based on their economic impacts. The activity-based costing approach in the parametric cost estimation model begins with defining general activities and their cost drivers. Activities, cost drivers, and cost centers can be identified through the results of field observations and maps of the operation process of producing Li-ion battery packs for e-motorcycle conversion. Some studies are used as a reference in the determination of cost driver and parameter costs, including research conducted by Sutopo, Nizam, Purwanto, Atikah and Putri [20]; W. Sutopo; A. Eliza; R. Ardiansyah; Yuniaristanto; and M. Nizam. Parametric [21], MY Abu; KR Jamaludin; and MA Zakaria [22], Fog [33], Erick Ten Bright [34], Katrin and Tatjana [35]. 
Table 1. Cost Driver and Cost Center Identification

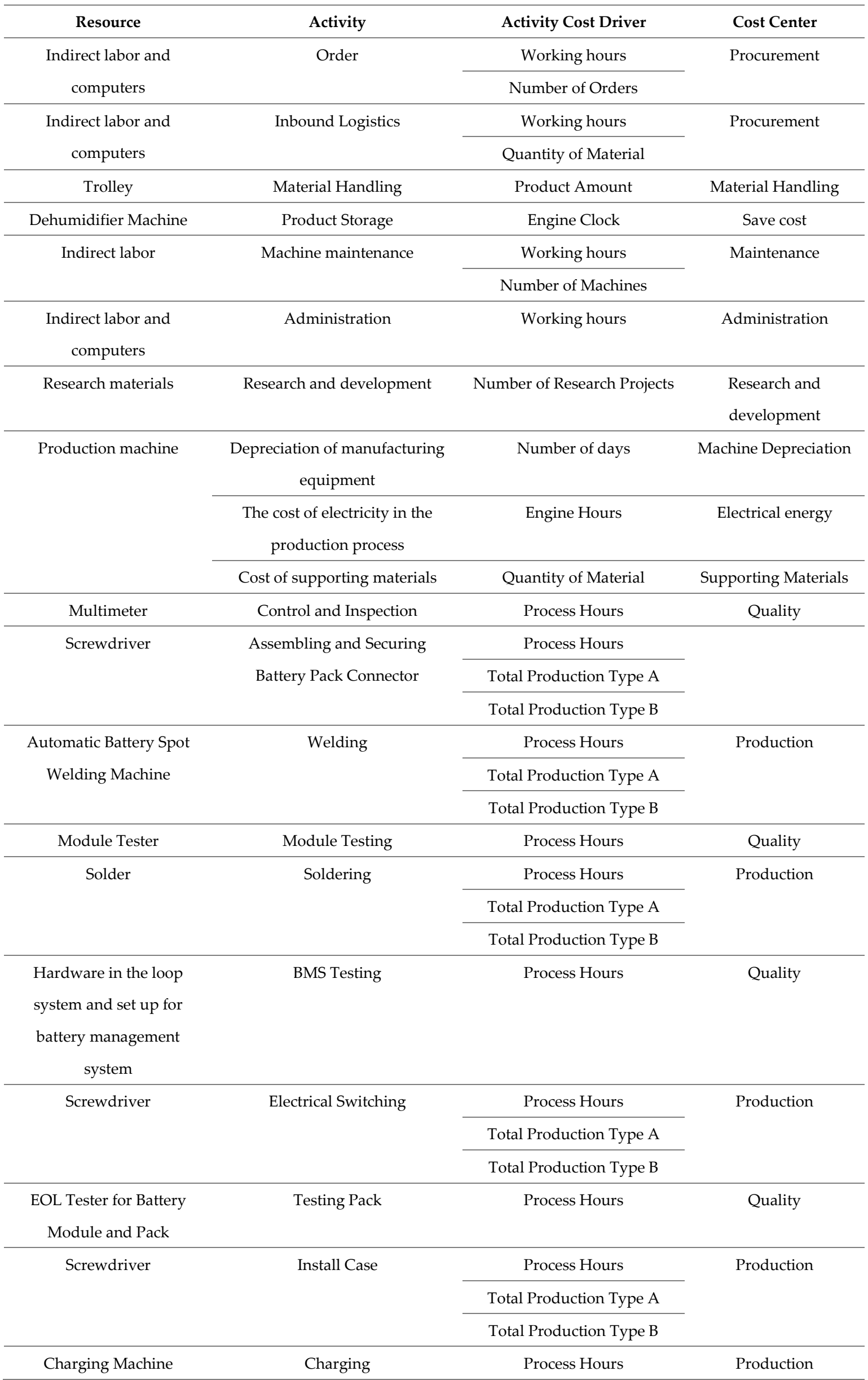




\begin{tabular}{cccc}
\hline Resource & Activity & Activity Cost Driver & Cost Center \\
\hline $\begin{array}{c}\text { EOL Tester for Battery } \\
\text { Module and Pack }\end{array}$ & Final Testing & Process Hours & Quality \\
\hline
\end{tabular}

\subsection{Parametric Cost Estimation Model Development}

In calculating the cost estimation model with the activity-based costing approach, it can generally be done by multiplying the cost driver rate by the number of driving activities as in equation (1).The cost driver rate is the cost that must be incurred for each activity undertaken. The equation (2) is used to calculate cost driver rates.

$$
\begin{gathered}
C_{j}=\sum_{k=1}^{K}\left(R_{j k} x Q_{j k}\right) \\
R_{j k}=\frac{T A_{j k}}{V_{j k}}
\end{gathered}
$$

Where $C_{j}$ is activity costs $\mathrm{j}, R_{j k}$ is cost driver k for activity $\mathrm{j}, Q_{j k}$ is number of activity in activity, $T A_{j k}$ is total activity costs $\mathrm{j}, V_{j k}$ is the predicts number of activity drivers $\mathrm{k}$ in activity $\mathrm{j}$.

The total cost of the activity considers several things. In indirect activities, it is necessary to consider overhead costs such as indirect labor costs, machine depreciation costs, electricity costs, consumables costs, and other costs that support these activities. Whereas the direct activity costs that are considered in the calculation of activity costs are the direct labor cost and raw material costs.

\subsection{Monte Carlo Simulation}

In this research, monte Carlo simulations are carried out to produce data on the amount of production, considering that the battery pack is a new product with no historical data. The monte Carlo simulation through the generation of random numbers is performed using the function on equation (3). This data is used in multiple linear regression analysis to analyze the variables that affect the cost of making a battery pack at SMART UNS.

$$
=\text { RAND }()^{*}(\text { Max Prod-Min Prod })+(\text { Min Prod })
$$

\section{Results and Discussion}

\subsection{Parametric Cost Estimation Model}

Through business processes and field observations, it was found that there were ten indirect activities and 11 direct activities. Through these activities, the cost driver is identified to build a parametric cost estimation model. Table 2 shows the parametric cost estimation model with an

\begin{tabular}{|c|c|c|}
\hline Activity & Activity Cost Driver & Parametric Model \\
\hline \multirow[t]{2}{*}{ Order } & Working hours & \multirow{2}{*}{$C o=\left(R o_{1} x h\right)+\left(R o_{2} x Q o\right)$} \\
\hline & Number of Orders & \\
\hline \multirow[t]{2}{*}{ Inbound Logistics } & Working hours & \multirow{2}{*}{$C i=\left(R i_{1} \times h\right)+\left(R i_{2} \times Q o\right)$} \\
\hline & Amount of Material & \\
\hline Material Handling & Product Amount & $C m h=R m h \times Q m h$ \\
\hline Product Storage & Engine Hours & $C p p=R p p \times h_{m}$ \\
\hline Machine maintenance & Working hours & $\mathrm{Cmm}=\mathrm{Rmm} \times \mathrm{Hm}$ \\
\hline Administration & Working hours & $\mathrm{Cad}=\operatorname{Rad} \times \mathrm{Had}$ \\
\hline Research and development & Number of Research Projects & $C r d=\operatorname{Rrd} x Q r d$ \\
\hline $\begin{array}{l}\text { Depreciation of manufacturing } \\
\text { equipment }\end{array}$ & Number of days & $C d m=R d m \times Q d m$ \\
\hline
\end{tabular}
activity-based costing approach.

Table 2. Parametric Cost Estimation Model Based on Activity 


\begin{tabular}{ccc}
\hline $\begin{array}{c}\text { The cost of electricity in the } \\
\text { production process }\end{array}$ & Engine Hours & Cel $=$ Rel $x h_{m}$ \\
\hline Cost of supporting materials & Amount of Material & Cim $=$ Rim $x$ Qim \\
\hline Quality Assurance Activities & Process hour & $C q c=R q c \times h_{q c}$ \\
\hline Production Activity & Process Hours & $C l_{j}=R l_{j} \times h_{j}$ \\
\cline { 2 - 3 } & Total Production Type A & $C m_{i j}=\sum_{i=1}^{n}\left(R m_{i j} x Q_{i j}\right)$ \\
\cline { 2 - 3 }
\end{tabular}

\subsection{Numerical Example}

In this section, an estimated battery-pack production cost is calculated for one period. This section begins with calculating the cost driver rates for each activity using equation two and calculates the production cost using the parametric cost estimation model in table 2. Table 3 is a recapitulation of the calculation of cost driver rates for each activity.

Table 3. Recapitulation of cost driver rates

\begin{tabular}{|c|c|c|}
\hline Activity & Activity Cost Driver & Cost Driver Rates (USD) \\
\hline \multirow[t]{2}{*}{ Order } & Working hours & 0.76 \\
\hline & Number of Orders & 2541.19 \\
\hline \multirow[t]{2}{*}{ Inbound Logistics } & Working hours & 0.76 \\
\hline & Amount of Material & 0.01 \\
\hline Material Handling & Product Amount & 0.05 \\
\hline Product Storage & Engine Clock & 0.30 \\
\hline Machine maintenance & Working hours & 1.63 \\
\hline Administration & Working hours & 0.87 \\
\hline Research and development & Number of Research Projects & 5450.68 \\
\hline $\begin{array}{c}\text { Depreciation of } \\
\text { manufacturing equipment }\end{array}$ & Number of days & 238.30 \\
\hline $\begin{array}{c}\text { The cost of electricity in the } \\
\text { production process }\end{array}$ & Engine Hours & 4.91 \\
\hline Cost of supporting materials & Amount of Material & 4.12 \\
\hline Control and Inspection & Process Hours & 6.04 \\
\hline Assembling and Securing & Process Hours & 2.06 \\
\hline \multirow[t]{2}{*}{ Battery Pack Connector } & Total Production Type A & 3.69 \\
\hline & Total Production Type B & 2.64 \\
\hline \multirow[t]{3}{*}{ Welding } & Process Hours & 6.18 \\
\hline & Total Production Type A & 370.08 \\
\hline & Total Production Type B & 264.64 \\
\hline Module Testing & Process Hours & 2.06 \\
\hline \multirow[t]{3}{*}{ Soldering } & Process Hours & 2.06 \\
\hline & Total Production Type A & 2.50 \\
\hline & Total Production Type B & 2.50 \\
\hline BMS Testing & Process Hours & 2.06 \\
\hline Electrical Switching & Process Hours & 2.06 \\
\hline
\end{tabular}




\begin{tabular}{ccc}
\hline Activity & Activity Cost Driver & Cost Driver Rates (USD) \\
\hline & Total Production Type A & 0.55 \\
\cline { 2 - 3 } & Total Production Type B & 0.55 \\
\hline Testing Pack & Process Hours & 2.06 \\
\hline Install Case & Process Hours & 2.06 \\
\cline { 2 - 3 } & Total Production Type A & 9.67 \\
\cline { 2 - 3 } & Total Production Type B & 9.67 \\
\hline Charging & Process Hours & 2.06 \\
\hline Final Testing & Process Hours & 2.06 \\
\hline
\end{tabular}

The calculation uses the parametric cost estimation model in table 2 for a period of 1 month with total production for type A is 40 units and type B for 35 units. Table 4 is calculated the estimated costs for total production and unit costs of each type of li-ion battery pack for e-motorcycle conversion. Detailed calculations of estimated production costs for one month are shown in Appendix A2.

Table 4. The Result of Calculating the Estimated Costs (USD)

\begin{tabular}{cccc}
\hline Battery-pack & $\begin{array}{c}\text { Total Production } \\
\text { Cost }\end{array}$ & Production Cost & Unit Production Cost \\
\hline Battery-pack Type A & $\mathbf{4 3 2 6 9 . 6 7 1}$ & 25096.1881 & 627.4046818 \\
Battery-pack Type B & & 18173.48315 & 519.2423972 \\
\hline
\end{tabular}

\subsection{Simulation Design}

In this section, the Monte Carlo simulation design for the number of lithium-ion battery pack production for e-motorcycle conversion. Monte Carlo simulation aims to develop data that will be used to analyze multiple linear regression models. Monte Carlo simulations can predict errors from simulations that are proportional to the number of iterations. For new products, the specified error value is $58 \%$ [36]. Equation (4) to calculate the number of iterations needed to get a result with an error of $58 \%$.

$$
N=\left(\frac{3 x \sigma}{\varepsilon}\right)
$$

Where $N$ is the number of iterations, $\sigma$ is a standard deviation, and $\varepsilon$ is an error value. The results of the calculation of the number of repetitions using equation (4) are 1512 iterations. Table 5 is the result of random numbers generated through the RAND function of Microsoft Excel using equation (3) and the calculation of estimated costs using the parametric model in table 2.

Tabel 5. Li-ion Battery-pack Production Data

\begin{tabular}{ccccccc}
\hline Iterate & $\begin{array}{c}\text { Battery Pack } \\
\text { Type A }\end{array}$ & $\begin{array}{c}\text { Unit } \\
\text { Production } \\
\text { Cost } \\
\text { (USD) }\end{array}$ & $\begin{array}{c}\text { Battery Pack } \\
\text { Type B }\end{array}$ & $\begin{array}{c}\text { Unit } \\
\text { Production } \\
\text { Cost } \\
\text { (USD) }\end{array}$ & $\begin{array}{c}\text { Total } \\
\text { Production Cost } \\
\text { (USD) }\end{array}$ \\
\hline $\mathbf{1}$ & $\mathbf{3 8}$ & 612.34 & $\mathbf{3 4}$ & 504.15 & $\mathbf{7 2}$ & 40411.00 \\
\hline $\mathbf{2}$ & $\mathbf{3 5}$ & 628.75 & $\mathbf{3 2}$ & 520.63 & $\mathbf{6 7}$ & 38665.55 \\
\hline $\mathbf{3}$ & $\mathbf{3 6}$ & 632.32 & $\mathbf{3 0}$ & 524.20 & $\mathbf{6 6}$ & 38489.53 \\
\hline $\mathbf{3 6}$ & $\mathbf{3 7}$ & 618.66 & $\mathbf{3 3}$ & 510.47 & $\mathbf{7 0}$ & 39734.40 \\
\hline $\mathbf{5}$ & $\mathbf{3 8}$ & 609.32 & $\mathbf{3 5}$ & 501.13 & $\mathbf{7 3}$ & 40695.13 \\
\hline $\mathbf{1 5 0 8}$ & $\mathbf{3 7}$ & $\mathbf{\vdots}$ & $\mathbf{3 2}$ & 513.76 & $\mathbf{6 9}$ & 39450.26 \\
\hline $\mathbf{1 5 0 9}$ & $\mathbf{4 0}$ & 621.89 & $\mathbf{3 4}$ & 498.25 & $\mathbf{7 4}$ & 41195.65 \\
\hline $\mathbf{1 5 1 0}$ & $\mathbf{3 8}$ & 6186.37 & $\mathbf{3 2}$ & 510.47 & $\mathbf{7 0}$ & 39842.59 \\
\hline $\mathbf{1 5 1 1}$ & $\mathbf{3 9}$ & 639.87 & $\mathbf{2 5}$ & 531.68 & $\mathbf{6 4}$ & 38245.62 \\
\hline $\mathbf{1 5 1 2}$ & $\mathbf{3 8}$ & 618.66 & $\mathbf{3 2}$ & 510.47 & $\mathbf{7 0}$ & 39842.59 \\
\hline
\end{tabular}




\subsection{Estimation of Multiple Linear Regression Models}

This section analyzes multiple linear regression to establish the relationship between the dependent and independent variables. There are 3 regression models built, the first regression model to determine the total cost of producing lithium-ion battery packs for e-motorcycle conversions. The second and third regression models are used to determine the cost of production per unit of lithiumion battery packs for Type A and Type B. In calculating cost estimation using activity-based costing, costs are triggered by the existence of resource usage activity. Each activity has an activity cost driver that determines the number of costs incurred according to the resources used. Wagner (2012) stating that production volumes are a fundamental trigger cost. Therefore, independent variables in multiple linear regression analyses used the number of total production and the number of battery-pack production for type A and type B. This section is used IBM SPSS Statistics 25 software to estimate the regression model between the dependent variable and the independent variable. $1^{\text {st }}$ Model :

$$
y=15839.108+108.162 x_{1}+284.190 x_{2}
$$

$y$

$x_{1}$

$x_{2}$

$2^{\text {nd }}$ Model :

$y$

$x_{1}$

$x_{2}$

3 rd Model :

$y$

$x_{1}$

$x_{2}$

: Total cost of production (USD)

: Total production of lithium-ion battery packs for Type A (Unit)

: Total production of lithium-ion battery packs (Unit)

$$
y=864.806-0.016 x_{1}-3.505 x_{2}
$$

\subsection{Classical Assumption Test}

The classic assumption test aims to provide certainty that the regression equation obtained has accuracy in estimation, is unbiased and consistent. The classical assumption test consists of 4 parts, namely, multicollinearity, autocorrelation, heteroscedasticity, and normality.

\begin{tabular}{|c|c|c|c|}
\hline \multicolumn{4}{|c|}{ Coefficients } \\
\hline \multirow{2}{*}{\multicolumn{2}{|c|}{ Model }} & \multicolumn{2}{|c|}{ Collinearity Statistics } \\
\hline & & Tolerance & VIF \\
\hline \multirow[t]{4}{*}{1} & (Constant) & & \\
\hline & Total production of battery-packs Type A & .793 & 1.261 \\
\hline & Total production of battery packs & .793 & 1.261 \\
\hline & a. Dependent Variable: Total cost of pro & & \\
\hline \multirow[t]{3}{*}{2} & (Constant) & & \\
\hline & Total production of battery-packs Type A & .793 & 1.261 \\
\hline & Total production of battery packs & .793 & 1.261 \\
\hline & a. Dependent Variable : Unit production c & battery $\mathrm{Ty} 1$ & \\
\hline \multirow[t]{4}{*}{3} & (Constant) & & \\
\hline & Total production of battery-packs Type A & .793 & 1.261 \\
\hline & Total production of battery packs & .793 & 1.261 \\
\hline & a. Dependent Variable : Unit production c & battery Ty & \\
\hline
\end{tabular}

Table 6. Multicollinearity Test Results 


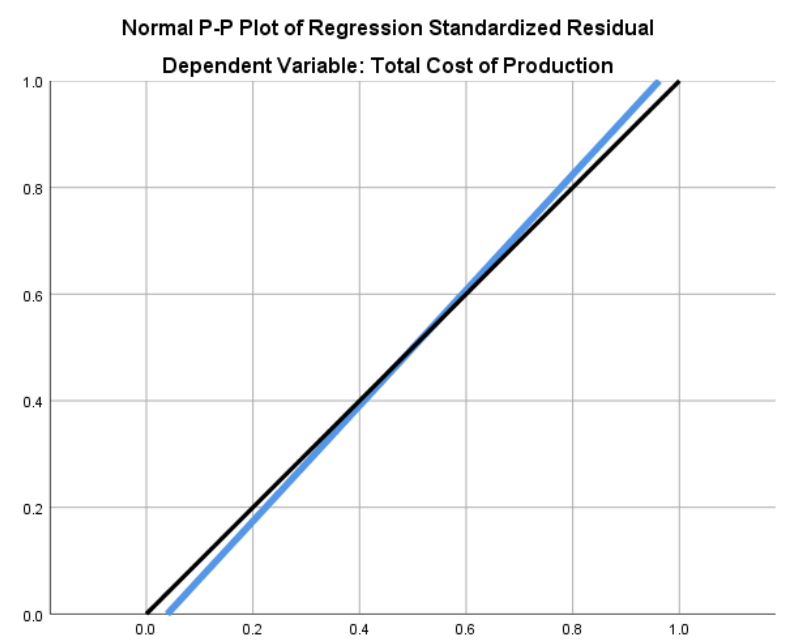

(a)

Normal P-P Plot of Regression Standardized Residual Dependent Variable: Unit Producton Cost of Battery-pack Type A

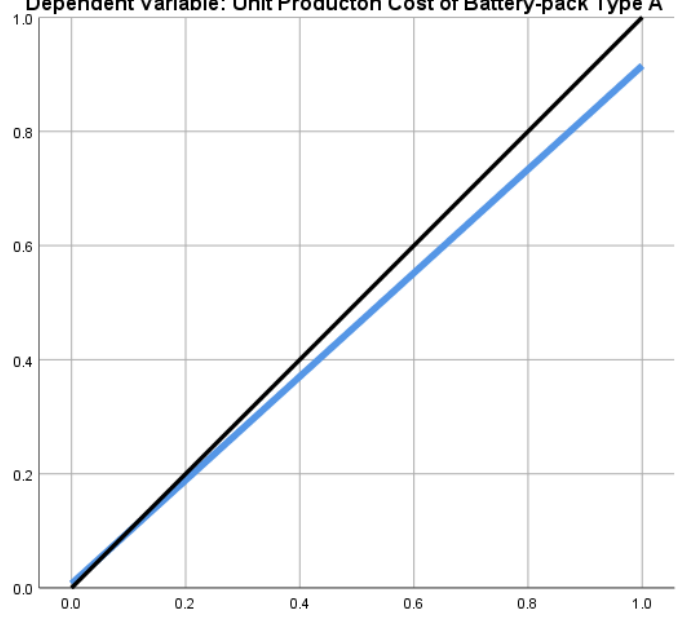

(b)
Normal P-P Plot of Regression Standardized Residual Dependent Variable: Unit Production Cost of Battery-pack Type B

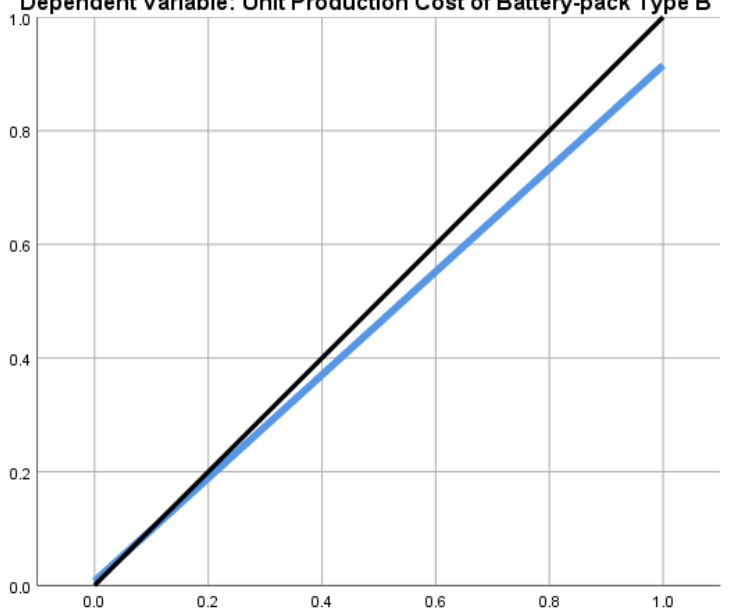

(c)

Figure 3. Normal Plot Graph (a) Model 1; (b) Model 2; (c) Model 3

Based on Figure 3 it is known that the distribution of points is relatively close to the diagonal line so that the residual data criteria are normally distributed with the Normal Plot approach.

\subsection{Model Feasibility Test}

In this section, test the estimation of the regression model that has been formed in section 3.4 to measure the accuracy of the regression model in estimating the actual value. This section uses the $\mathrm{F}$ test and the $\mathrm{T}$ test.

3.6.1 F Test

In this section, an $\mathrm{F}$ test is performed to determine whether the independent variables simultaneously affect the dependent variable. 2 hypotheses are used. In general, these two hypotheses are:

a. $\mathrm{HO}=$ Simultaneous independent variables do not significantly influence the dependent variable.

b. H1 = Simultaneous independent variables simultaneously have a significant effect on the dependent variable.

Hypothesis testing is done by comparing the significance value with $5 \%$. If the significance value $<0.05$ then $\mathrm{H} 0$ is rejected, and if the significance value $>0.05$ then $\mathrm{H} 0$ is accepted. 
Table 9. F Test Results

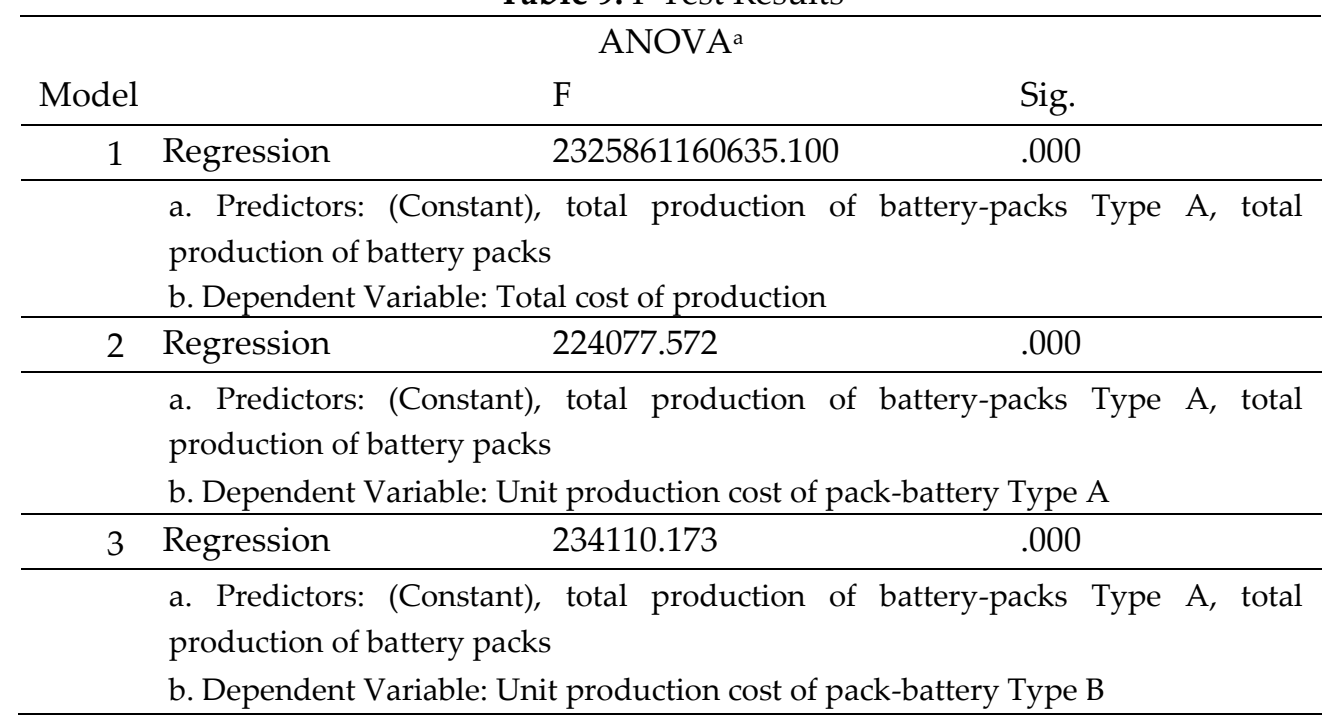

Because the significance value $<0.05$, the three models have a simultaneous influence between the independent variables on the dependent variable.

\subsubsection{T Test}

T-test is a method of testing the model to determine the effect of each regression coefficient on the dependent variable. There are 2 hypotheses are used, in general these two hypotheses are:

a. $\mathrm{H} 0=$ The independent variable has no significant effect on the dependent variable.

b. $\mathrm{H} 1=$ The independent variable has a significant effect on the dependent variable.

Hypothesis testing is done by comparing the significance value with $5 \%$. If the significance value $<0.05$ then $\mathrm{H} 0$ is rejected, and if the significance value $>0.05$ then $\mathrm{H} 0$ is accepted.

Table 10. T Test Result

\begin{tabular}{|c|c|c|c|c|}
\hline \multicolumn{4}{|c|}{ Coefficients $^{a}$} & \multirow[b]{2}{*}{$\begin{array}{l}\text { Significant } \\
\text { Influence }\end{array}$} \\
\hline Model & & $\mathbf{t}$ & Sig. & \\
\hline \multirow[t]{3}{*}{1} & (Constant) & 1241735.455 & .000 & \\
\hline & Total production of battery-packs Type A & 305884.845 & .000 & $\mathrm{~V}$ \\
\hline & Total production of battery packs & 1761879.852 & .000 & $\mathrm{~V}$ \\
\hline \multicolumn{5}{|c|}{ a. Dependent Variable: Total cost of production } \\
\hline \multirow[t]{3}{*}{2} & (Constant) & 1858.380 & .000 & \\
\hline & Total production of battery-packs Type A & -1.228 & .228 & $X$ \\
\hline & Total production of battery packs & -595.543 & .000 & $\mathrm{~V}$ \\
\hline \multicolumn{5}{|c|}{ a. Dependent Variable: Unit production cost of pack-battery Type A } \\
\hline \multirow[t]{3}{*}{3} & (Constant) & 1662.276 & .000 & \\
\hline & Total production of battery-packs Type A & -1.206 & .285 & $x$ \\
\hline & Total production of battery packs & -608.751 & .000 & $\mathrm{~V}$ \\
\hline \multicolumn{5}{|c|}{ a. Dependent Variable: Unit production cost of pack-battery Type B } \\
\hline
\end{tabular}

Based on table 10 it is known that in 1st model the independent variables have a significant effect on the dependent variable. In 2nd model it is known that the total variable production of battery type A pack does not have a significant effect on the dependent variable, while the total production variable has a significant effect on the dependent variable. Then the 3rd model it is known that the total variable production of battery type A pack does not have a significant effect on the dependent variable, while the total production variable has a significant effect on the dependent variable. Although there are non-significant variables in the second and third models, the model can still be used because if the model runs simultaneously, significant variables will influence the insignificant variables. 


\subsection{Determination of the Most Influential Variables}

To find out the independent variables that most influence the dependent variable, use the Standard Coefficient Beta test. The highest beta coefficient marks the independent variable that has the biggest effect.

Table 11. Beta Coefficient

\begin{tabular}{|c|c|c|c|}
\hline \multicolumn{4}{|c|}{ Coefficients $^{a}$} \\
\hline \multicolumn{2}{|r|}{ Model } & $\begin{array}{c}\text { Standardized } \\
\text { Coefficients Beta }\end{array}$ & $\begin{array}{c}\text { Most Influential } \\
\text { Variables }\end{array}$ \\
\hline \multicolumn{4}{|c|}{1 (Constant) } \\
\hline & Total production of battery-packs Type A & 159 & $\mathbf{X}$ \\
\hline & \multicolumn{3}{|c|}{ a. Dependent Variable: Total cost of production } \\
\hline \multicolumn{4}{|c|}{2 (Constant) } \\
\hline & Total production of battery-packs Type A & .002 & $\mathbf{X}$ \\
\hline & Total production of battery packs & -.997 & $\mathbf{V}$ \\
\hline & \multicolumn{3}{|c|}{ a. Dependent Variable: Unit production cost of pack-battery Type A } \\
\hline \multicolumn{4}{|c|}{ (Constant) } \\
\hline & Total production of battery-packs Type A & .002 & $\mathbf{X}$ \\
\hline & Total production of battery packs & -.997 & $\mathbf{V}$ \\
\hline \multicolumn{4}{|c|}{ a. Dependent Variable: Unit production cost of pack-battery Type B } \\
\hline
\end{tabular}

The relation of total cost per unit with change of the activity output is known by reviewing the behavior of cost [37]. In literature, the cost behavior is described as fixed or variable with respect to changes in production volumes. Volumes of output as the fundamental cost driver. Variable costs change proportionally to the change in production volumes [38]-[39]. In standard cost models, variable costs change proportionately with changes in the activity driver, implying that the magnitude of a change in costs depends only on the extent of a change in the level of activity, not on the direction of the change [40].

Based on the first model, it is known that the number of production variables has the highest beta coefficient, 0.917 . Therefore, production costs are more influenced by the number of production variables compared to other variables. The factor owned by the total variable production is positive, this shows that if the total production increases, the total production cost will increase as well. Based on the second model, it is known that the number of production variables has the highest beta coefficient, which is 0.997 . Therefore, production costs are more influenced by the number of production variables compared to other variables. The coefficient owned by the total production variable is negative, this shows that if the total production increases, the production cost of type $\mathrm{A}$ battery units will be smaller. Based on the third model it is known that the number of production variables has the highest beta coefficient value, which is 0.997 . Therefore, production costs are more influenced by the number of production variables compared to other variables. The coefficient owned by the total production variable is negative, this shows that if the total production increases, the cost of producing a B type battery unit will be smaller. In this study when the assumption expanded by enlarging the value of significance then it is possible that the $\mathrm{H} 0$ can be accepted even if it is wrong and resulting in a change of influence between the dependent variables to the independent variables.

Based on the analysis, the company can maximize the amount of production according to the production capacity to reduce the cost of unit production. By maximizing the amount of production, the price of the product can be more competitive. To achieve production capacity, the company can create an operation process chart and apply standard operational procedures without override product quality.

\section{Conclusions}

This research chooses an activity-based costing method to classify the cost of producing a Li-ion battery pack for e-motorcycle conversion. Activity-based costing methods provide a more accurate 
view of product costs than traditional cost methods by identifying each activity element's entire cost. This method determines all activities related to the production process, allocates costs for these activities, and helps classify the production process costs more easily and faster.

The activity-based costing method is integrated with the parametric cost estimation method, which is the right method to be applied with the estimated cost of producing a Li-ion battery-pack for e-motorcycle conversion through a mathematical model. Cost estimation results that reflect a significant difference between product specifications. In addition, cost estimation also reflects the overall use of the company's resources. Activity-based costing helps companies in resource management to get a more competitive cost. Moreover, changes in the operation process for cost reduction will allow the company to fulfill customer needs. Therefore, the battery-pack company can use the activity-based costing method to accurately estimate the cost.

This research also used the regression analysis to analyze. The results of data processing show that the total production costs and unit production costs of the two types have the greatest influence on the total production. However, the total production variable has a different effect on the calculation of total production costs and unit production costs. In the calculation of the total production costs, if the amount of production is increases, the total production costs will increase. Whereas in the calculation of unit production costs it is known that if the total production amount increases, the unit production costs will decrease.

Author Contributions: Conceptualization, W.S. and S.D.S; methodology, S.D.S, and W.S, YA.; validation, W.S, and YA; data curation, S.D.S and R.W.A.; writing-original draft preparation, S.D.S.; writing-review and editing, W.S and YA..; visualization, S.D.S.; supervision, W.S, YA., and R.W.A. All authors have read and agreed to the published version of the manuscript.

Funding: This research was partially funded by the Indonesian Ministry of Research, Technology, and Higher Education under the WCU program, managed by Institut Teknologi Bandung.

Acknowledgments: This paper was supported by USAID through Sustainable Higher Education Research Alliances (SHERA) Program-Centre for Collaborative (CCR) National Center for Sustainable Transportation Technology (NCSTT) with grant No. IIE00000078-ITB-1.

Conflicts of Interest: The authors declare no conflict of interest. 


\section{Appendix A}

Table A1. Notation Description

\begin{tabular}{|c|c|}
\hline Notation & Description \\
\hline Co & Order Fees (USD) \\
\hline $\mathrm{Ci}$ & Logistics inbound costs (USD) \\
\hline$R o_{1}$ & Fixed fee per hour for order activities (USD / order) \\
\hline$h$ & Working hours (hours) \\
\hline $\mathrm{Ro}_{2}$ & Tariff for one order (USD / order) \\
\hline Qo & Order Amount (order) \\
\hline$R i_{1}$ & Fixed fee per hour for inbound logistic activities (USD / order) \\
\hline$R i_{2}$ & Inbound logistics tariff per unit of material (USD / unit) \\
\hline$Q i$ & Amount of material (unit) \\
\hline$i$ & Order number \\
\hline $\mathrm{Cmh}$ & Material handling costs (USD) \\
\hline$R m h$ & Hourly Material Handling Rates (USD / unit) \\
\hline$Q m h$ & Number of products (units) \\
\hline$C p p$ & Storage fee (USD) \\
\hline$R p p$ & Product hourly storage rate (USD / hour) \\
\hline$h_{m}$ & Engine hours (hours) \\
\hline $\mathrm{Cmm}$ & Machine maintenance costs (USD) \\
\hline Rmm & Hourly engine maintenance rate (USD / hour) \\
\hline$H m m_{i}$ & Number of technician working hours (hours) \\
\hline Crd & Research and development costs (USD) \\
\hline $\operatorname{Rrd}$ & Research rates per research project (USD / project) \\
\hline Qrd & Amount of research projects (Projects) \\
\hline Cad & Administration fee (USD) \\
\hline Rad & Hourly administration fee (USD) \\
\hline Had & Total administrative hours (hours) \\
\hline$C d m$ & Cost of depreciating machinery and production equipment (USD) \\
\hline$R d m$ & $\begin{array}{l}\text { Depreciation rates for machinery and production equipment per day } \\
\text { (USD / unit) }\end{array}$ \\
\hline$Q d m$ & Number of days in a month (unit) \\
\hline $\mathrm{Cel}$ & Production machine electricity costs (USD) \\
\hline Rel & Electric machine production hourly (USD / hour) \\
\hline Cim & Cost of supporting materials (USD) \\
\hline Rim & Rates of auxiliary materials per unit (USD / unit) \\
\hline Qim & Amount of auxiliary material used (unit) \\
\hline Cqc & Quality control costs (USD) \\
\hline$R q c$ & Hourly quality control and inspection rates (USD / hour) \\
\hline$h_{q c}$ & Number of QC hours (hours) \\
\hline $\mathrm{Cl}$ & Direct labor costs (USD) \\
\hline $\mathrm{Cm}$ & Material cost (USD) \\
\hline
\end{tabular}




\begin{tabular}{cl} 
Notation & \multicolumn{1}{c}{ Description } \\
$R l$ & Hourly direct labor rates (USD / hour) \\
$R m_{i}$ & Material tariff for series i battery packs per unit battery pack (USD / unit) \\
$Q_{i}$ & Number of pack-battery (unit) production \\
$i$ & Type of battery pack \\
$j$ & Activity Type \\
\hline
\end{tabular}




\section{Appendix B}

Table A2. Calculation of Estimation Cost (USD)

\begin{tabular}{|c|c|c|c|c|c|c|}
\hline Activity & Cost & $\begin{array}{l}\text { Cost Driver } \\
\text { Rates }\end{array}$ & Quantity & $\begin{array}{l}\text { Unit Production } \\
\text { Cost Type A }\end{array}$ & $\begin{array}{c}\text { Unit Production } \\
\text { Cost Type B }\end{array}$ & Total \\
\hline \multirow[t]{2}{*}{ Order } & Order activity overhead & 0.764 & 200 & 81.487958 & 71.301963 & 152.789922 \\
\hline & Charge order fees & 2541.187 & 1 & 1355.299696 & 1185.887234 & 2541.186929 \\
\hline \multirow[t]{2}{*}{ Inbound Logistics } & Inbound logistic overhead & 0.764 & 200 & 81.487958 & 71.301963 & 152.789922 \\
\hline & Material costs & 0.009 & 43980 & 234.357737 & 146.820268 & 381.178005 \\
\hline Material Handling & Material handling costs & 0.046 & 75 & 1.830622 & 1.601794 & 3.432416 \\
\hline Product Storage & Save cost & 0.296 & 525 & 82.910273 & 72.546488 & 155.456761 \\
\hline Machine maintenance & Machine maintenance costs & 1.629 & 200.0 & 173.796053 & 152.071547 & 325.867600 \\
\hline Administration & General \& administrative costs & 0.936 & 200 & 99.794175 & 87.319904 & 187.114079 \\
\hline Research and development & Research and development costs & 5450.676 & 1 & 2907.027299 & 2543.648887 & 5450.676186 \\
\hline $\begin{array}{l}\text { Depreciation of manufacturing } \\
\text { equipment }\end{array}$ & $\begin{array}{l}\text { Depreciation of manufacturing } \\
\text { equipment }\end{array}$ & 204.934 & 30 & 3278.940294 & 2869.072758 & 6148.013052 \\
\hline $\begin{array}{l}\text { The cost of electricity in the } \\
\text { production process }\end{array}$ & $\begin{array}{l}\text { The cost of electricity in the } \\
\text { production process }\end{array}$ & 3.674 & 525 & 1028.643827 & 900.063349 & 1928.707176 \\
\hline Cost of supporting materials & Cost of supporting materials & 4.119 & 1 & 2.196746 & 1.922153 & 4.118899 \\
\hline Control and Inspection & Labor costs & 27.344 & 4.52 & 65.988739 & 57.740147 & 123.728885 \\
\hline Assembling and Securing Battery & Labor costs & 2.061 & 25.34 & 27.852706 & 24.371118 & 52.223824 \\
\hline \multirow[t]{2}{*}{ Pack Connector } & Material costs for Type A & 372.744 & 40 & 14909.754926 & & 14909.754926 \\
\hline & Material costs for Type B & 266.246 & 35 & & 9318.596828 & 9318.596828 \\
\hline \multirow[t]{3}{*}{ Welding } & Labor costs & 6.183 & 12.67 & 41.779059 & 36.556677 & 78.335736 \\
\hline & Material costs for Type A & 1.030 & 40 & 41.188989 & & 41.188989 \\
\hline & Material costs for Type B & 1.030 & 35 & & 36.040365 & 36.040365 \\
\hline
\end{tabular}




\begin{tabular}{|c|c|c|c|c|c|c|}
\hline Activity & Cost & $\begin{array}{c}\text { Cost Driver } \\
\text { Rates }\end{array}$ & Quantity & $\begin{array}{c}\text { Unit Production } \\
\text { Cost Type A }\end{array}$ & $\begin{array}{c}\text { Unit Production } \\
\text { Cost Type B }\end{array}$ & Total \\
\hline Module Testing & Labor costs & 2.061 & 13.57 & 14.921093 & 13.055956 & 27.977049 \\
\hline \multirow[t]{3}{*}{ Soldering } & Labor costs & 2.061 & 12.67 & 13.926353 & 12.185559 & 26.111912 \\
\hline & Material costs for Type A & 2.504 & 40 & 100.171621 & & 100.171621 \\
\hline & Material costs for Type B & 2.504 & 35 & & 87.650168 & 87.650168 \\
\hline BMS Testing & Labor costs & 2.061 & 13.57 & 14.921093 & 13.055956 & 27.977049 \\
\hline \multirow[t]{3}{*}{ Electrical Switching } & Labor costs & 2.061 & 27.15 & 29.842185 & 26.111912 & 55.954097 \\
\hline & Material costs for Type A & 0.549 & 40 & 21.967461 & & 21.967461 \\
\hline & Material costs for Type B & 0.549 & 35 & & 19.221528 & 19.221528 \\
\hline BMS Testing & Labor costs & 2.061 & 13.57 & 14.921093 & 13.055956 & 27.977049 \\
\hline \multirow[t]{3}{*}{ Install Case } & Labor costs & 2.061 & 9.05 & 9.947395 & 8.703971 & 18.651366 \\
\hline & Material costs for Type A & 9.666 & 40 & 386.627308 & & 386.627308 \\
\hline & Material costs for Type B & 9.666 & 35 & & 338.298895 & 338.298895 \\
\hline Charging & labor costs & 2.061 & 54.30 & 59.684370 & 52.223824 & 111.908194 \\
\hline \multirow[t]{3}{*}{ Testing Pack } & Labor costs & 2.061 & 13.57 & 14.921093 & 13.055956 & 27.977049 \\
\hline & & \multicolumn{2}{|c|}{ Total Production Cost } & 25096.188 & 18173.483 & 43269.671 \\
\hline & & \multicolumn{2}{|c|}{ Unit production cost of pack-battery } & 627.405 & 519.242 & 576.929 \\
\hline
\end{tabular}




\section{References}

1. Ministry of Industry. 2018. Avaible online: https://kemenperin.go.id/artikel/1984/Laju-IndustriSepeda-Motor (accessed on 14 Januari 2020).

2. Sadeghinezhad, E.; Kazi, S. N.; Sadeghinejad, F.; Badarudin, A.; Mehrali, M.; Sadri, R.; and Safaei, M. R. A comprehensive literature review of bio-fuel performance in internal combustion engine and relevant costs involvement. Renewable and Sustainable Energy Reviews. 2014, 30, $29-44$.

3. Statistical Review of World Energy 69th Edition. 2020. Available Online : https://www.bp.com/content/dam/bp/business-sites/en/global/corporate/pdfs/energyeconomics/statistical-review/bp-stats-review-2020-full-report.pdf (Accesed on : 20 June 2020)

4. E. Uherek, et al. Transport impacts on atmosphere and climate: Land transport. Atmospheric Environment 44. 2010, 4772-4816. DOI: 10.1016/j.atmosenv.2010.01.002.

5. Shiying Wang \& Mengpin Ge. 2019. Everything You Need to Know About the Fastest-Growing Source of Global Emissions: Transport. World Research Institute. Available online: https://www.wri.org/blog/2019/10/everything-you-need-know-about-fastest-growing-source-globalemissions-transport (Acessed on 27 June 2020)

6. James Hansen, et al. Global Temperature in 2019. 2020. Available online : http://www.columbia.edu/ jeh1/mailings/2020/20200115 Temperature2019.pdf (Accessed on 27 June 2020)

7. Al-Alawi, B. M., \& Bradley, T. H. Review of hybrid, plug-in hybrid, and electric vehicle market modeling Studies. Renewable and Sustainable Energy Reviews, 2013, 21, 190-203. DOI: 10.1016/j.rser.2012.12.048

8. Guerra, E. Electric vehicles, air pollution, and the motorcycle city: A stated preference survey of consumers' willingness to adopt electric motorcycles in Solo, Indonesia. Transportation Research Part D: Transport and Environment, 2017. DOI:10.1016/j.trd.2017.07.027

9. Chang, Y. \& Y. Li. 2019. Electric Vehicles and Energy Insecurity in ASEAN Countries: Renewable Energy Integration and Urban Air Quality. ADBI Working Paper 1025. Tokyo: Asian Development Bank Institute. Available Online : https://www.adb.org/publications/electricvehicles-energyinsecurity-aseancountries (Accessed on : 20 June 2020)

10. Mutyala, Srinivas. Design and Development of Electric Motorbike. International Research Journal of Engineering and Technology (IRJET), 12 December 2019; 6(12), 19-29. ISSN: 2395-0072.

11. Godlewski T., and Pawlak W. Design of supporting frame for light electric motorcycle. 12th Students' Science Conference, Oficyna Wydawnicza Politechniki Wrocławskiej, 2015; 303-309. ISSN 1732-0240.

12. R. Nasiri-Zarandi and M. Ebrahimi. Extracting requirements for design a two-wheels electric vehicle and proposing a design procedure. 9th Annual Power Electronics, Drives Systems and Technologies Conference (PEDSTC),Tehran, 2018; pp. 462-468. doi: 10.1109/PEDSTC.2018.8343841

13. Nizam, M. Comparative study of electric vehicles in urban area in Indonesia. AIP Conference 485 Proceedings (Vol. 2217, No. 1, p. 030141). AIP Publishing LLC, 2020.

14. W. Sutopo; N. Atikah; A. Purwanto; D. P. T. D. Danardono and M. Nizam. A cost estimation model to assess the feasibility of Li-Ion battery development based on targeted cost by market approach. 2014 International Conference on Electrical Engineering and Computer Science (ICEECS). 2014, 376-380. DOI : 10.1109/ICEECS.2014.7045281.

15. Carloni, Andrea \& Baronti, Federico \& Di Rienzo, Roberto \& Roncella, Roberto \& Saletti, Roberto. Open and Flexible Li-ion Battery Tester Based on Python Language and Raspberry Pi,2018, Electronics, 7.,454. DOI : 10.3390/electronics7120454.

16. Becker, Jan \& Nemeth, Thomas \& Wegmann, Raphael \& Sauer, Dirk. Dimensioning and Optimization of Hybrid Li-Ion Battery Systems for EVs. World Electric Vehicle Journal, 2018, 9. DOI 10.3390/wevj9020019.

17. R. Ardiansyah, W. Sutopo \& M. Nizam. A parametric cost estimation model to develop prototype of electric vehicle based on activity-based costing, 2013 IEEE International Conference on Industrial Engineering and Engineering Management, Bangkok. 2013, 385-389. DOI:10.1109/IEEM.2013.6962439

18. Horngren,Charles T., et al. Akuntansi Biaya. Edisi 7. 2008. PT INDEKS GRAMEDIA: Jakarta.

19. Ben-Arieh, David \& Qian, Li. Activity-based cost management for design and development stage. International Journal of Production Economics. 2003, 83, 169-183. DOI:10.1016/S0925-5273(02)00323-7. 
20. W. Sutopo, M. Nizam, A. Purwanto, N. Atikah, AS Putri. A Cost Estimation Application for Determining Feasibility Assessment of Li-Ion Battery in Mini Plant Scale. International Journal on Electrical Engineering and Informatics. 2016, 8 (1), 189-199. DOI : 10.15676/ijeei.2016.8.1.13

21. W. Sutopo; A. Erliza; R. Ardiansyah; Yuniaristanto; and M. Nizam. Parametric Cost Estimation for Controlling the Development of Electric Vehicle Prototype. Jurnal Mekanikal. 2016, 3956-68.

22. MY Abu; KR Jamaludin; and MA Zakaria. Characterisation of activity based costing on remanufacturing crankshaft. International Journal of Automotive \& Mechanical Engineering. 2017, 14 (2), 4211-24. https://doi.org/10.15282/ijame.14.2.2017.8.0337

23. Sharma, R., \& Ratnatunga, J. Teaching note: Traditional and activity based costing systems, Accounting Education, 2007, 6(4), 337-345. http://dx.doi.org/10.1080/096392897331406

24. Raz, T., \& Elnathan, D. Activity based costing for projects. International Journal of Project Management, 1999, 17(1), 61-67. http://dx.doi.org/10.1016/S0263-7863(97)00073-2

25. Geri, N.; \& Ronen, B. Relevance lost: the rise and fall of activity-based costing. Human Systems Management, 2005, 24(2), 133-144.

26. Oduoza, C.F. Reflections on costing, pricing and income measurement at UK higher education institutions. Journal of Higher Education Policy \& Management, 2009, 31(2), 133-147. http://dx.doi.org/10.1080/13600800802559328

27. Cokins, G., \& Capusneanu, S. Cost Drivers. Evolution and Benefits. Theoretical and Applied Economics, 2010, 8(549), 7-16.

28. Sheng, Y.M. Research on selection methods of cost driver. Journal of Modern Accounting and Auditing, 2009, 5(9), 52, 47-49.

29. Geiger, D. R. Practical Issues in Cost Drivers Selection for Managerial Costing System. The Government Accountants Journal, 1999, 48(3), 32.

30. Ravas, B., \& Monea, A. The definition and determination of the cost drivers, basis elements in the ABC system implemented in a tourism unit. Lucrari Stiintifice, 2009, 11(4), 1-6.

31. Dražic-Lutilsky, I., \& Dragija, M. Activity based costing as a means to full costing-possibilities and constraints for European universities. Journal of Contemporary Management Issues, 2012,17(1), 33-57.

32. Percevic, H., \& Dražic-Lutilsky. Cost Allocation Accounting Methods Used in the Croatian Production Sector. South East European Journal of Economics \& Business, 2008, 3(1), 49-57. DOI: 10.2478/v10033008-0006-8.

33. Fong, C.C. and Kumar, N. 2002, Cost Accounting, 2nd ed., HKAAT.

34. Erick ten Brinke. 2002. Costing support and cost control in manufacturing A cost estimation tool applied in the sheet metal domain. PrintPartners Ipskamp, Enschede, The Netherlands. ISBN 90-3651726-5.

35. Katrin T \& Tatjana P. Theoretical Framework and an Overview of the Cost Drivers that are Applied in Universities for Allocating Indirect Costs. Procedia - Social and Behavioral Sciences 110, 2014, 1014 1022. doi: 10.1016/j.sbspro.2013.12.948

36. Kahn, Kenneth B. An Exploratory Investigation of New Product Forecasting Practices. The Journal of Product Innovation Management 19, 2002, 133-143.

37. Riwayadi. Akuntansi Biaya.Pendekatan Tradisional dan Kontemporer. 2014. Jakarta: Salemba Empat. ISBN : 9789790615373

38. Hansen, Don R., Mowen, M. M. \& Guan, L. Cost management: accounting \& control, 6th ed. 2009. Mason: South-Western. ISBN : 9780324559675.

39. Weygandt, J., Kimmel, J. P. D. \& Kieso, E. D. (2010), Managerial accounting: tools for business decision making, 5th ed. Hoboken, NJ: John Wiley \& Sons. ISBN : 978-1-119-40405-7

40. Novák, P., Popesko, B. Cost Variability and Cost Behaviour inManufacturing Enterprises, Economics and Sociology, 2014, Vol. 7, No 4, pp. 89-103. DOI: 10.14254/2071-789X.2014/7-4/6. 